\title{
Ownership Concentration in the TV Industry
}

\author{
A Case Study on the Limitations of Media Policy
}

\author{
SUNE TJERNSTRÖM
}

\begin{abstract}
The wish to limit ownership concentration in the media industry has been common in the newspaper sector, but hardly very successful. As commercial television was more extensively introduced, governments saw possibilities of limiting ownership concentration in this sector. One such case is the Swedish TV4, owned at the start in 1991 by a consortium of financial and smaller publishing groups, but now controlled by the biggest player in the national media business. What happened on the way and what were the obstacles to media policy in this field? Some would argue that this is an area in which media policy failed. Alternatively, this development can be understood as a case in which the nature of corporate policy is revealed. A third option would be to observe the interaction between corporate interests and the government as an example of so-called political management. This article examines these scenarios in the context of commercial television in Sweden. The case study provides a deeper understanding of the nature of 'institutional competitiveness', politics vs. business, nationally based media firms vs. other Scandinavian players.
\end{abstract}

Key Words: media policy, corporate strategy, political management, hybrid media firms, TV4 Sweden

\section{Introduction}

Fearing that private broadcasters could overrun the monopoly of the Swedish public service broadcaster in the late 1980s, the government decided to organize a new national 'commercial public service' channel. ${ }^{1}$ An agreement was made between the government and a private consortium on TV broadcasting over the terrestrial net. ${ }^{2}$ This new public service firm - or hybrid organization as they are often called - was given a virtual monopoly on TV advertising reaching the whole country. The price the consortium would have to pay consisted of a number of obligations, fees and restrictions ${ }^{3}$ :

- obligations regarding content, roughly the same as for the non-commercial public service broadcaster (excluding minority programs)

- obligations to broadcast news on a regional basis, in addition to the national coverage.

- a fee for using the terrestrial net that was based on advertising revenues ${ }^{4}$

- restrictions regarding changes in ownership, obviously aiming at reducing ownership concentration in commercial $\mathrm{TV}$. 
The content restrictions, of which the demand for a qualified news operation was the heaviest burden, were estimated to cost the new TV firm some SEK 100 mill ( $€ 11$ mill) annually (Tjernström 1998). The regional structure to be organized was minimal and not much of a financial burden initially, although the figures for regional television were estimated to remain in the red for some time. The fees for use of the terrestrial network turned out to be considerable. Given the rise in advertising revenue, however, the initial fees amounted to a modest SEK 50 million ( $€$ 5.5). This was an issue that would arise in later negotiations as the fee rose according to an agreed-upon formula: Was it too high to leave sufficient funds for programs?

The ownership restrictions were no problem to begin with, given the strong financial position of the main shareholders and the limited ownership changes. But as years passed and the original owners showed an interest in disinvesting and other media industry actors were anxious to strengthen their position in the TV industry, this issue turned out to be quite problematic.

The problem was: To what extent were options open to the Swedish government to prevent ownership concentration in commercial television?

The wider framework concerns the feasibility of government regulation: Is it government policy or corporate policy and market forces that determine major developments in the media industries? Or, as some would say, do technological forces determine the development of new systems? The case of the first Swedish commercial TV channel may be an illustrative example of the limitations of media policy and the many faces of corporate policy that interfere with government ambitions.

\section{Purpose of the Study and Material Used}

The purpose of this article is to analyze - against the background of an institutional framework - the changes in ownership in the commercial public service broadcaster established in 1991 and to suggest possible theoretical frames of reference for understanding this development.

\section{Perspectives of Interpretation}

Three broad scenarios will be suggested, which encompass the differing perspectives of interpretation. One such theoretical background involves understanding the processes described in terms of media concentration policy; this means seeing developments from the government's perspective. From a corporate perspective, another scenario involves observing the changes in TV4 ownership as the result of classical corporate strategy. Political management, which involves the interaction of government and corporate perspectives, is a third possible frame of interpretation. Changes in ownership in this broadcasting company will also be studied within a wider industrial context, considering the strategies of other organizations in the global media market. We are dealing here with 'institutional competitiveness', politics vs. business, nationally based media firms vs. global players - or at least Scandinavian ones (Lund 2005).

\section{A Few Central Concepts}

Media policy is often defined as actions by the government in the media sector (Østbye 1997). Others define media policy in terms of the many actors that influence the goals, means and time schedules of government projects (Hutchison 1999). Or, interpreted in 
terms of agency theory, as a question of influence on rules and regulations, with the public and industry as principals, Congress and the White House as intermediaries, and the FCC, the bureaucratic policy maker, as the agent (Napoli 2001/2003). Media policy can also be seen as an effort to protect national culture versus economic logic or as the interaction between the pursuit of national interests by states and the operation of commercial enterprises (Siune 1998; van Cuilenberg \& McQuail 2003). Media policy, then, may be defined as the result produced by initiatives from these main actors, the government and business interests.

Media concentration implies that the supply of media is dominated by few, rather than many different owners (Doyle 2002). Media concentration is measured as the degree of influence of a limited number of owners, business groups, over the media; often the weight of four (CR4) or eight publishers (CR8) is estimated (Stuhlfaut 2005). Measurements may involve one sector at the time or refer to the total influence over many media sectors. This study concerns diversity of ownership in the TV sector. Because the study's focus is on rules concerning ownership of a TV company, it concerns diversity of output (Aslama et al. 2004). This approach is taken in full awareness of the possible impact of more concentrated media ownership on socio-political and cultural pluralism (Bagdikian 2004).

Media concentration policy has long been placed on top of the Swedish (and, e.g., Norwegian) media policy agenda; a number of royal commissions have dealt with the issue. For a long period of time, legislation was written and proposed but never implemented. This is often referred to as Lex Bonnier, which was supposed to deter the Bonnier family from expanding their Swedish media empire, primarily in the newspaper market. The Norwegian government has restrictions on newspaper ownership in force, which may explain some of the foreign ventures of the major media firms in Norway - expansion in their home market is restricted. This aspect of media policy limiting ownership concentration - in several Scandinavian countries is obviously part of the context of the case presented.

Corporate strategy concerns the pursuit of different lines of action by firms in attempts to enhance corporate profits or to increase shareholder wealth. In the classical sense, strategy sets the general direction in which the firm's position will grow and develop, all designed to maximize long-term advantage (Ansoff \& McDonnell 1990). For the classical approach, good planning is what it takes to master changing environments. Strategy matters in that rational analysis makes the difference between long-term success and failure. More recent versions of strategy theory place less emphasis on longterm fixed strategies and see strategy as something emerging from adjustment to competitive moves and to other changes in the environment (Whittington 1993).

Political management. To understand corporate behavior in relation to political ambitions, one may also need to rely on the vast field of research on political management or ideological-institutional leadership. For researchers who study public service firms, theories of political management have much to offer (Selznick 1957, Blondel 1987). This means understanding that these media firms are active in a political or institutional market in addition to catering to consumer needs and demands (Brunsson 1989). The main reason is the fact that the government determines several of the conditions for their presence in the market place. The nation-state continues to provide the basic frame of reference for media systems. In more general terms, political management is about interactions in policies and markets, globally and nationally (Chadha \& Kavoori 2005). 
Major changes in the electronic media can be regarded as the development of 'sociotechnical systems', such that technology depends on social reactions and decisions and administrative arrangements (Ewertsson 2001). Ewertsson quotes the late Mr. Stenbeck, the founder of the MTG Group (that is to feature prominently in this article): "Technology always beats politics", but she argues that most technological (media) systems depend on political decisions for their implementation. Political management concerns these dependencies between business, technology and politics and how, e.g., media firms behave to obtain advantages or avoid obstacles in the introduction of new media technology or business models (Ewertsson 2004).

Sometimes, it is claimed, the relationship between media corporations and government reaches forms that could be referred to as 'market corruption', non-aggression pacts or alliances, where private purposes replace the traditional watchdogs serving the public interest (Curran 2005).

\section{Method and Sources}

The method is basically historical, relying on media comments and other documentation from 1991 to the present concerning each major change in ownership. The sources drawn upon are - apart from official government sources - two general-interest newspapers, two business papers, and some additional media comments that contribute to our understanding of the development. ${ }^{5}$ The newspapers are

- The Dagens Nyheter (the largest newspaper in the country, published in Stockholm, owned by the Bonnier group, the major Swedish media actor; it is generally considered a liberal-leaning newspaper)

- The Svenska Dagbladet (the second largest newspaper in the capital, owned by the Norwegian Schibsted group; it is considered a conservative-leaning paper).

The business papers are:

- The Affärsvärlden (considered by many as the most qualified business or financial paper in the country, owned by Teknikförlaget, a smaller specialized publishing house).

- The Financial Times (that quite often comments on developments in the media industry worldwide for a European elite readership)

The material has been made available on the Internet through access to the files containing the publications.

\section{Ownership Changes in the New Commercial TV Channel}

Three phases of ownership changes are identified and analyzed in terms of media policy, corporate strategy and political management.

\section{The First Phase: a Consortium of Owners}

Preparations had been made long before the final negotiations for a license. Two entrepreneurs formed a company called Nordisk Television TV4 already in 1984, and made preparations for the new situation they felt must arise (a third channel). In 1985, they managed to attract funds from an investment firm that is to appear later in this story: 
Proventus. The entrepreneurs outlined what a private commercial broadcaster could do, emphasizing not least national drama series and national and regional news, all attractive ingredients in negotiations to come.

In 1987, they managed to attract a group of five investors with roughly equal shares in a new company. The group was heterogeneous in terms of main business interests and financial strength. ${ }^{6}$ What was conspicuous was the presence of strong industrial and financial actors outside the media sector of the economy and the absence of major media players in the group of shareholders.

An important change in ownership came somewhat unexpectedly during the negotiations for the license. The London-based Scandinavian satellite channel TV3, which was owned by Mr. Jan Stenbeck and his telecommunications and media group Kinnevik, agreed to withdraw from the competition in return for acquiring a significant shareholding in TV4, which was to be the sole bidder for the license (FT Nov. 1, 1991). The remaining bidder was then given the license.

The new centre-right government proposed that TV3 and TV4 should co-operate in managing the new channel, which was to compete against TV3 and the two non-commercial state-owned stations. The government's rationale for its merger proposal was that broader ownership would increase financial support for the new channel, which was expected to lose money until the end of the downturn in the economy (FT, Nov. 1, 1991).

\section{Analysis Phase I}

From a media concentration policy perspective, the composition of the consortium initially backing Nordisk Television TV4 seemed nearly ideal. Five major owners with links to different financial, industrial and union sectors of society had invested in the new company.

From a corporate strategy perspective, it was somewhat unclear what the consortium backing Nordisk Television TV4 had in mind; how many of them were seriously considering taking substantial risks to enter the TV business as a long-term investment; how many thought of their investment as an interesting financial investment that somebody else would reward them for?

The consortium seemed strong in terms of political management; it had the needed legitimacy, the currency needed in the negotiations; it had financial strength (the Wallenberg group, Sweden's largest industrial group), popular support (a union-owned insurance company SPP), political connections (the LRF group, traditionally linked to the centrist party in the new coalition government), analytical strength (the Föreningsbanken), entrepreneurial creativity (the creators of the company), and finally some media experience (the Natur \& Kultur publishing house - and LRF publishing activities). The latter was probably the weakest link in the owner set-up; no major media player was present in the first round.

The entrepreneurs in Nordisk Television TV4 were lobbying intensively to get the license. The entrepreneurs had quite a bit of goodwill with leading politicians, having stressed national content and news operations as guiding principles. They had been in contact with several other parties, including the Bonnier group and the Newspaper Publishers' Association, who had declined participation. The positive aspect of this limited media presence was that none of the major actors in the Swedish media market would increase their ownership in the new company. 
TV3, the competitor, owned by the Kinnevik group, had the media experience, but limited goodwill in government circles, as their channel, aimed at Scandinavia, had a very obvious entertainment profile and hardly any news operation worth mentioning. Jan Stenbeck, the heir of a substantial fortune in the steel industry, had worked successfully with his corporate strategy of crushing monopolies in the telecom sector; this was his main business strategy. It is possible that his reputation was somewhat better with the new non-socialist government than with the previous socialist government.

Yet, many observers were surprised at the outcome of the government negotiations. The outcome resulted in an increase in ownership concentration in the broadcasting market, as at the time the Kinnevik group was essentially the only industrial group that had previous interests in the television market, in TV3 and in satellite distribution. The major media group in the country, the Bonnier group, was absent from the negotiations. Other major Scandinavian media players, such as Norwegian Schibsted or the Finnish Sanoma group, were also not present at the table.

The Kinnevik group entered into a near-monopoly situation, quite a successful result of a corporate strategy aimed at threatening state monopolies in various telecom markets. It was hardly surprising that Sweden's Price and Competition Office criticized the new ownership structure of TV4, as it would give Mr. Stenbeck a strong position in the Swedish TV advertising market, which had grown rapidly since the start of TV3 in 1988 and TV4 in 1990 (FT, Nov. 1, 1991).

The government's room for maneuvering was limited in terms of influencing ownership concentration, given its wish to achieve several goals at the same time: widespread ownership, previous experience from television, and financial strength.

\section{The Second Phase: Public flotation by TV4}

Details of the first public flotation by a Swedish television company were announced in March 1994 when TV4 published the prospectus for a SEK 400 million (€ 95 mill) issue of a 20 percent share of the company.

TV4's largest shareholder at the time of the flotation was the Kinnevik group, which also controlled TV3. Investor, the main investment vehicle of the Wallenberg family, also held 25 percent. The other original investors were still major owners of TV4. Among the new owners was the American Fidelity Trust.

In 1997, Investor, in the Wallenberg group, sold its holding in TV4 to Aamulehti, a Finnish media group. The sale marks a strategic shift for Investor, which had media as one of its growth sectors. It had increased its stake in TV4 as recently as the previous year. However, Claes Dahlbäck, Investor CEO, suggested the group lacked the profound knowledge and commitment necessary to succeed in the sector.

By 2001, following some reshuffling of holding company structures, the largest owners of TV4 shares were the Bonnier group and the Finnish Alma Media group, owner of a large number of newspapers in Finland and owner of MTV3, the Finnish private TV channel, financed by advertising. Because the Bonnier group had large interests in Alma Media, it was in fact controlling TV 4 and made this clear by ousting the board members nominated by the Kinnevik-held MTG group, despite the fact that MTG held 20 percent of the shares and was the third largest holder. Overnight, MTG ownership was turned into a so-called financial investment, which generally means that shares are for sale if the price is right (Afv 010403). In May 2002, the MTG group sold 5 percent of its shares to the Bonnier group, giving the signal that it was giving up on TV4 control. 
Meanwhile, Marita Ulvskog, Sweden's Media Minister, complained that the TV4 sale by the Wallenberg group would increase concentration of media ownership in Sweden. The Bonnier group from then on controlled 40 percent of TV4 votes. Ms. Ulvskog warned that the deal could have legislative implications and could affect renewal of the TV4 license (FT Oct. 22 1997).

\section{Analysis Phase II}

The entry of TV4 into the Stock Exchange was neutral in terms of media concentration. It could mean a further spread in ownership or it could mean increased concentration. It opened the way, however, for corporate initiatives from other players. One of these initiatives was the early disinvestment of the Wallenberg group; another was the increased holdings of the Bonnier group, directly and indirectly. The government could hardly force an industrial group like the Wallenberg group to maintain ownership in a venture that was no longer in their strategic focus.

From a media concentration perspective, Bonnier's control over TV4 was demonstrating that, despite the government's ambitions, the big player had the last word. Throwing out MTG's board members seems to have been a commercially justified move, and it made it clear to a larger audience that from now on Bonnier called the shots.

From a corporate strategy perspective, it seemed that Bonnier felt the time and the price were right, and that this was their opportunity to make a definitive move into the commercial TV market, adding another media sector to their existing media interests. The Wallenberg group, on the other hand, felt that broadcasting was not in their longterm plans and disinvested, at a handsome profit.

The Bonnier group was not the ideal owner of TV4, as the government saw it, but there was little the government could do. And the group did not waste any time on political management.

To sum up, it seems that, once again, the government's options were indeed limited.

\section{An Episode: TV3 Makes a Bid for the License}

When the license was up for renewal starting in 2006, TV3 and the MTG group made another bid for the contract, promising a regional news operation and accepting the previous high fee for terrestrial broadcasts (DN 041214).

TV3's bid was taken seriously and evaluated by the government, which gave TV3 a certain legitimacy the company had not previously enjoyed. At the same time, the generous position at the negotiation table cost their competitor, TV4, a great deal of money, which may have been the whole idea. As expected by most observers, in December 2004, TV4 was finally granted a renewal of the license (DN 041222). The conditions were harsher than expected: The company was to increase its regional broadcasts, cultural and children's programs (Afv041222). About SEK 400 mill a year was to be paid in fees for the right to broadcast via the terrestrial net for the last two years of its existence (all broadcasts will be digital by 2008) (Afv 041229).

\section{Analysis of TV3's Bid}

In terms of media concentration, there would have been a reduction in the number of actors in the Swedish television market had TV3 been granted the license at the renewal 
stage. The Bonnier group, who were controlling TV4, would have seen their position marginalized, and the MTG group would have enjoyed the undisputed leading role in commercial TV.

From a corporate strategy perspective, TV3 increased its competitive position visà-vis TV4, forcing TV4 to strike back, offering the government a more costly operation. The increased demands placed on TV4, including a 30-minute regional news broadcast in 16 regions and programs reflecting the country's 'multi-cultural' status, may in the long run be the key to placing TV4 in a favored position among the public service channels, e.g. when discussing its 'must carry' status in the new digital net. And some additional favors may be in the pipeline, when its privileged position in the terrestrial net ends (SvD 051223).

The actor with most legitimacy was the incumbent TV4. The company had to pay the price for the generous position of TV 3 at the negotiating table. The fees were kept and additional costs were added. Paradoxically, TV3 seemed to have mastered the political management field - maybe not too surprising given that one of their advisors was the previous Minster of Industry and Communication, Björn Rosengren (Holmkvist 2005).

The only feasible solution for the government was to select TV4 - if the company agreed to pay as much as TV3 had offered.

\section{The Third Phase: A Battle between Two Nordic Media Giants}

Around midsummer of 2004, the Norwegian media group Schibsted started buying shares in Finnish Alma Media, the Finnish bridge-head of the Bonnier media empire. Schibsted raised its stake in TV4 from 5 to 20 percent and launched an unsolicited bid of Euros $705 \mathrm{~m}$ ( $€ 75$ mill) the same week for Alma Media, which in turn controlled 23.4 per cent of TV4 (DN 041221). Schibsted's bid, offering a 30 percent premium on Alma Media stock and sound long-term value, had to gain the acceptance of more than onethird of Alma Media shareholders, among them Bonnier, which controlled 33 percent of Alma Media (FT Dec. 23 2004). Schibsted was the number one media group in Norway, owning major newspapers and 33 percent of the Norwegian commercial channel, TV2.

Alma Media was vital to the Bonnier group. Alma's ownership of TV4's Finnish equivalent, MTV3, made it the key to power over two of the most important TV channels in Scandinavia. Remaining ownership in Alma was distributed among a few institutions, among them six Finnish insurance companies, whose CEOs could all fit in one sauna, as one observer put it.

Schibsted, in January of 2005, bought an option for an additional 5.9 percent in TV4, stepping up its fight to wrest control of Sweden's largest commercial channel from Bonnier. Schibsted bought the option from LRF, the Swedish agricultural union, which was a member of the original consortium. If exercised, the option would take Schibsted's stake to 26 percent (FT Jan. 4 2005).

For the time being, the Bonnier group was left in a controlling position (Afv 040915). The purchase by Schibstedt of additional shares from Fidelity, an American investment company, was seen by the Bonnier family as a provocation (DN 041216; SvD 050126). As Schibsted had interests the Norwegian equivalent, TV2, its pan-Scandinavian vision became apparent. One of the reasons for Schibstedt's aggressive behavior outside Norway is probably the fairly strict limitations on ownership concentration that apply in Norway. 
Bonnier and Schibsted had aggressively moved to expand their media businesses in the Nordic region. We were obviously witnessing a war between media giants in Scandinavia, all of whom wanted to control commercial television in the region. The four target companies were:

- TV4 of Sweden

- TV2 of Norway

- TV2 of Denmark

- MTV3 of Finland

The four commercial/public service channels were very much alike, culturally and economically, and played leading roles in their respective TV markets. Together their audiences amounted to some one-third of the population of the four countries; their turnover was slightly more than SEK 7 bill.seven ( $€ 800$ mill.). Profitability varied, the average profit margin was some 5 percent in 2003, an extremely weak year in terms of advertising volumes. Synergies were expected from the joint ownership of all four (Afv 041005 and 041006). Not all observers were ready to assign figures to these synergies.

Simultaneously, TV4 entered an alliance with the Danish media group Berlingske (owned by Orkla, the Norwegian media firm challenging Schibstedt's dominance in Norway) to make a bid for the Danish TV2, which was about to be privatized (the Danish State put up 50\% shares for sale). The Danish government wishes to retain more than 40 percent in TV2 and has said that price will not be the deciding factor, leading many to believe that political factors may well be crucial on the Danish media scene (FT, Jan. 10, 2005). The bidder with the lowest odds at this stage seemed to be a Danish consortium of newspaper and magazine publishers (Politiken, Jyllands-Posten and Egmont). Egmont owned a third of Norwegian TV2, alongside Schibstedt, making it an interesting Nordic player.

Clearly, the pan-Scandinavian vision was alive among the major media actors (Afv 041110). Schibsted, which had extensive newspaper interests in Norway and Sweden, hoped to build a pan-Nordic television platform, providing the opportunity to co-operate across all four wealthy, but comparatively small European markets. Despite the increasing penetration of satellite and cable channels and broadband networks, the terrestrial broadcasters are seen as valuable for their strong established brands and market shares (FT Jan 25 2005).

A few days earlier, another original owner, the Natur \& Kultur publishing house, announced that it had sold its shares in TV4 (Afv 041223). The buyer, the Bonnier group, thereby increased its TV4 share to slightly less than 28 percent. The sellers explained matter-of-factly that the Bonnier group had offered a higher price than Schibstedt had (DN 041223).

The Bonnier group had unexpected things up their sleeves. There seemed now to be two keys to TV4 control. One was the 15 percent shares still held by MTG/Kinnevik, which could be seen as the immediate key to control over TV4, and the other was control of Alma Media.

A new actor appeared on the scene when Proventus, a Swedish investment group that specializes in restructuring companies with strong brands, appeared to have stopped Schibsted's plans (FT Jan. 25 2005). Proventus (that put up the 'seed money' for the original entrepreneurs) announced that it had purchased Kinnevik's TV4 shares, at a 
considerable premium, making it one of the major shareholders (Afv 050107). The CEO of Proventus announced that it was a long-term investment and that an immediate sale (to Schibsted or Bonnier) was out of the question. He said he believed TV4 was a leading player in the restructuring and other changes that the television would undergo in the near future (Afv 050107). Proventus also acquired some 8 percent of shares and 15 percent of votes in Alma Media. Sellers were Suomi, Pohjola, and Ilmarinen, Finnish insurance companies (Afv 050110, SvD 050110).

The restructuring of the TV market was immediate. Bonnier, the Swedish media group, and its partner Proventus, a few weeks later agreed to pay $€ 460$ mill for the broadcasting assets of Finland's Alma Media, thwarting Schibsted's plans to build a panNordic commercial television group (FT Jan. 25 2005). The broadcasting activities in Alma Media included the previously mentioned MTV3, the majority in the Finnish radio station Radio Nova, and 23.4 percent of Swedish TV4 shares. The battle over TV4 was finished for the time being. The Bonnier group seemed to have won the battle over Swedish commercial television. Bonnier's and Proventus's total ownership in TV4 would amount to 66 percent (Afv 050124). The week's winner, however, seemed to be SBS Broadcasting (owner of Kanal 5), who bought Canal Plus at SEK 2.4 bill ( $€ 260$ mill.). TV4 and MTG replied immediately by cooperating on Viasat (SvD 050212).

However, Bonnier could still face political hurdles. Almost immediately, Leif Pagrotsky, Sweden's Minister of Culture, said he was "disappointed" about the increased concentration of media ownership the move entailed and would examine whether it breached TV4's broadcasting agreement (FT Jan. 25 2005). Another hurdle was the Stock Exchange. If there was indeed a 'pact' between the cooperating actors, Bonnier and Proventus, they would be forced to offer all other shareholders the same price as paid in the fight over control of the company. The parties denied any such pact, although it was well known that the owner of Proventus was a long-time friend of the Bonnier family (SvD 050113). Part of the deal (which was not allowed to be a deal) between Bonnier and Proventus emerged a few months later, when Proventus CEO was elected Chairman of the Board of TV4 and of the newly created Finnish holding company. The Bonnier CEO stepped down; apparently Proventus was to take the lead in restructuring the Scandinavian TV market. Schibsted, which had lost the fight over TV4, was allowed to send a member to the TV4 Board of Directors.

\section{Analysis of the Battle between the Two Nordic Media Giants}

Had Schibsted won the battle, TV4 control would have passed from one media giant to another, from Bonnier to Schibsted, which would hardly have mattered very much. From a media concentration point of view, given Schibsted's limited presence in Sweden, the government may have seen the ownership change as a slight improvement.

The pan-Scandinavian corporate strategies were new to politicians, but somewhat attractive at the same time. In the business press, some doubts were raised about synergies that could be achieved by owning several similar channels in three countries. One former CEO of TV4 declared publicly that he did not feel that the earning power of TV4 could justify the prices paid for TV4 in the bid to take it over (and even less so in the counter-attacks) (Afv 050111). For other shareholders, the TV4 share was 'dead' and not easy to sell (SvD 050131).

The Schibsted group had managed their previous Swedish holdings well, leaving the left-leaning editorial position of the Aftonbladet intact and maintaining a level of com- 
petition among newspapers in the Stockholm region with their morning paper the Svenska Dagbladet, despite prior heavy losses. They were considered a conservative group and ruthless capitalists, but were at least a change from total Bonnier dominance in all media sectors in Sweden. The group had recently announced that they were ready to disinvest in the Swedish movie business, putting their subsidiary up for sale. From a political management perspective, they had played their cards well.

From a media concentration point of view, nothing much had actually happened with Bonnier's victory in the battle. TV4 was already more or less in the hands of the Bonnier group. Bonnier and Proventus increased their control over Finnish commercial television, but completely relinquished their control over Finnish regional newspapers. In the Swedish media market, there were now two major Swedish owners in control of TV4. Whether this is in line with the 'limited ownership concentration' clause of the prolongation of the license is still an open question, one that must be settled by the Minister of Culture. There are pros and cons: On the one hand, in terms of control over TV4, nothing has changed; the Bonnier group continues to dominate. On the other hand, it seems provocative to a layman when two owners, obviously in some sort of partnership, go from modest (although controlling) ownership, including another Swedish media giant as a sort of balance among owners and a Finnish media group among major owners, to a situation in which the two own 66 percent of the company.

The Bonnier group's corporate strategy seems straightforward enough. Its position as the leading actor in commercial television (alongside the MTG group) was threatened and the only response possible was one that regained its original position. For financial and maybe other reasons, it was necessary to join forces with a reliable Swedish actor, which may contain the seed to future problems, but at least the hostile attack by the Norwegian group could be fought off. As with most strategies, there was a price to pay: reduced influence in the Finnish newspaper market. The pan-Scandinavian aspect of corporate strategy would in the end depend on the Danish government, and demands from the Danish partner, the Berlingske group. Maybe there will be additional prices to pay before the battle over the Danish channel is over. Another price linked to the strategy pursued was the heavy indebtedness required for the two partners to obtain the final 66 percent of TV4, possibly paying too high a premium for the additional shares (Melesko 2005). Some observers claimed that MTG was the overall winner in the fight between the two other corporate players, having sold their TV4 shares at a very high premium (SvD 050211). Others see Proventus as the future key player in the strategic development of the Nordic TV market (SvD 050111). Robert Weil, the Proventus chairman, was labeled the new 'joker in TV4', and he immediately announced plans to take the lead in the restructuring that lay ahead (SvD 050108). The Proventus CEO taking over as Chairman of TV4 and the Finnish holding company was an indication of this suggested leadership. The inclusion of a Schibsted Executive on the Board of Directors should be seen as another move in restructuring the Scandinavian TV market.

From a political management perspective, increased Bonnier power over TV4 (on paper) was hardly welcomed by the authorities. Bonnier was after all the most dominant media group in the country and much legislation had been proposed and considered to stop the group from becoming too influential, primarily in the newspaper market. Politically, the Schibsted attempt at controlling TV4 had caused the traditional suspicion of Bonnier dominance to surface again - hardly an improvement on an earlier situation in which ownership in TV4 was distributed among a number of shareholders, among those the MTG group and some of the original shareholders who were once awarded the 
first license. On the surface, the ownership picture had been one of calm and balance - although the Bonnier group was in total control. Now with nothing gained in terms of control, the official picture was less attractive for the partners. The presence of Proventus, a new owner, was welcomed by Leif Pagrotsky, the Minister of Culture. It "contributes to diversity", he was quoted as saying (SvD 050112).

The government was again left without any feasible alternatives. It was basically stuck with the present owners of TV4 and the little diversity Proventus could offer.

\section{Discussion - Perspectives of Interpretation}

Media concentration policy, corporate policy and political management are the three theoretical perspectives that guide the present analysis of the empirical material. Rephrasing the question posed in the introduction: To what extent is it possible to see ownership changes in the third Swedish channel, TV4, in the light of these three scenarios or theories? Do they help our understanding of government and corporate behavior?

The idea is that the developments in the Swedish commercial/ public service TV company were influenced by the government's media concentration policy and by corporate strategies to increase revenues, reduce costs and risks, and by attempts to maintain and increase legitimacy in the eyes of the government - political management.

Attempts to limit ownership consolidation in the new commercial TV market may have seemed natural from a political perspective (and feasible) as the first consortium was applying for the license. We have seen that these attempts were not very successful in the end, as the biggest media group in the country finally secured controlling interests, together with what seems to be a partner. The idea that media policy should not be interpreted exclusively in terms of government measures finds support; media policy and resulting states of affairs seem to be better understood in terms of the interaction of government ambitions and corporate strategies, one form of institutional competition, where business interests often seem to dominate the outcomes.

Controlling TV4 made sense for the Bonnier group: It could control revenues from several outlets, books, magazines, movies, VCR/DVDs and commercial television. Reducing costs through synergies in a pan-Scandinavian deal by improving efficiency and streamlining operations seems to have been the ultimate goal of the Bonnier group as well as of the other major player, Schibsted. Now they may have to cooperate to obtain such goals, yet another form of institutional interaction.

It is also obvious from the case that this is not a clear-cut application of classical strategy theory in every respect. For the first two phases, we may conceive of the Bonnier group strategy as one of entering the commercial TV market. But developments in the third phase may need additional theoretical input. We may need a bit of what Whittington calls processual theory to understand what has happened (Whittington 1993). This is a line of strategy research that claims that strategy emerges more from a process of learning and compromise than from a rational series of decisions (Mintzberg 1987). No one is sure what the optimal strategy is; it emerges from a series of events, such that the actions of other players have a great influence on the outcome. Here, the attempt by the Norwegian media group to challenge Bonnier's position in TV4 forced the latter group to take a series of measures that involved a significantly increased financial strain without advancing the degree of influence in TV4. It seems that the latest development in the case is an illustration of the need for renewed emphasis on theories of strategy other than the classical approach. 
Strategy seems to be a process of organizational change whereby strategies emerge with much confusion and often without warning, owing to the unexpected behavior of markets and competitors. One has to "accept and work with the world as it is" (Whittington 1993, p. 23). Strategies seem to be a way in which corporations simplify a world that is complex and chaotic, full of unexpected events. Strategy is discovered in action (March 1976). "Smart strategists appreciate that they cannot always be smart enough to think through everything in advance" (Mintzberg 1987, p 69). The underlying strategic logic may be perceived only after a series of events not expected beforehand. What existed, then, in the Bonnier group, as well as in the competing Schibsted group, was a long-term build-up of important internal competencies, ready to be made use of when needed, including strategic networks. In this case, established networks or relationships on the part of the Bonnier group seem to have mattered (with the Finnish partners in Alma Media and with the local Swedish investor community). Schibsted's competencies, e.g., in dealing with their potential Finnish business partners seem to have been lacking to some extent.

The idea that corporations were behaving in such a way as to please that government in whose hands were held the conditions for a TV license and renewal of that license has found some limited support in the present paper. Especially in the battle for a first license, the consortium that was formed around the entrepreneurs seemed to have the necessary legitimacy to take on the responsibility for the first combined commercial and public service channel in the country (although in the end the original investors preferred to disinvest and one of the country's media moguls obtained controlling interest). In the attempts to have the license prolonged, TV4 likewise offered (had to offer) an attractive package of regional broadcasts and cultural and other broadcasting, in an obvious attempt to block the competitor, TV3. To sum up, some political management seems to have been needed, but only at times. In other periods, corporate interests could be pursued without paying much attention to government media policy as far as ownership concentration was concerned. One institution, business, dominated the other, the government - despite the fact that there were legal options for the government to intervene. Pragmatic options, however, were extremely limited.

The case stands out as an example of a media industry that relies upon a set of laws and regulations that help to define the rules of the game, but where industrial actors are willing to pay less attention to these rules when they do not serve their interests. The issue was how the government should and could intervene. The government chose to introduce guidelines about ownership concentration, and the initial partners were supposed to follow suit, not selling their shares in such a way that ownership concentration increased. With the exception of the Wallenberg group, the initial owners stood by their promise and kept their shares in TV4 up to the point at which it was obvious that other actors dominated the scene.

The Scandinavian media giants have used their size and strength to pursue strategies not generally available to smaller competitors. They have had access to large amounts of investment capital for expensive acquisitions; they could take advantage of the efficiencies resulting from economies of scale and scope, and absorb significant losses on some projects because a few other projects make up for these losses. The integration of these major firms may allow them to exploit synergy by packaging content so it is usable in different media. These media giants have been able to reduce financial risks in various ways, including diversification of holding. 
Their attempts to reduce risks often violate basic market principles of competition and replace these principles with oligopoly or monopoly behavior. The concentration of media ownership thus presents serious problems even by market standards.

The conclusion, then, seems to be that classic strategy theory and a model of emerging corporate strategy, involving a learning or reactive component, may have been most helpful in understanding media business dynamics in this case. Media policy stands out as the result of government attempts to regulate and corporate power to pursue its own interests. This power includes the ability to please government decision-makers when and where this is needed. The effects on media content are not known, but are the subject of a brief concluding remark.

\section{A Concluding Remark: Ownership and Content}

Does it matter who owns TV4? Can media concentration measures be seen as a means to obtaining something else? What if the Bonnier group dominates this channel and the Kinnevik group controls TV3 and SBS owns TV5? Are there any effects of ownership on the content in these channels? This is obviously very difficult to establish, although most observers would be able to distinguish three profiles. There may be - for market purposes - a sort of (secret) partitioning of the commercial TV market between the relatively 'serious' TV4, the general entertainment-oriented TV3 and the movie-oriented TV5. This division of the market may follow a commercial logic, regardless of who owns TV4. Or, for example, would the Kinnevik group have moved the position of TV4 closer to the entertainment profile where they have more experience, in the name of the convergence often observed in the commercial TV market? Would Schibsted have pursued a different programming policy than the Bonnier group did, relying on Schibsted's experience of allowing different types of political slants in their media empire? We may never find out, unless some of the actors let us know.

The Bonnier group's record of balancing a difficult role as majority owner in media firms has often been noted (Sundin 2002). Balancing their long-term profit interest with letting writers, journalists and editors have free access to the media content has long been a trade mark of the Bonnier family, at least in the past.

There is, however, a different, slightly more speculative angle. Was the government free to intervene in the ownership of TV4 that had become part of the Bonnier media empire? TV4 could after all be expected to play a major role in upcoming elections, and the political parties striving for renewed majority positions in Parliament (as opposed to the executive branch of government) could be expected to be careful with TV4. At what point would they risk a negative slant in one of the most powerful media of the country? From an overall political viewpoint, some caution would seem advisable. Is that why media concentration in TV4 was quietly accepted by the government despite legal possibilities to renegotiate, based on the terms of the license? Again, future autobiographies may give us some leads.

\section{Notes}

1. A government bill on TV advertising paved the way (Government Bill 1989:73).

2. The agreement was signed on November 111991.

3. The 'agreement' was replaced in 1996 with a 'license', to which were attached a number of conditions, within the framework of the 1996/97 Radio and TV Law (1996:844) 
4. A special law (1992.72) was introduced to cover TV4's fees.

5. The use of newspapers as sources for the case can be questioned, but they are readily available and their reliability has constantly been checked by references to other sources, e.g., the actors involved.

6. One shareholder was a medium-size book publisher, Natur \& Kultur, one was the business branch of the farmers' movement, LRF, which also ran a considerable publishing business, one was a capital investment company in the biggest industrial group in the country, one was a bank with a strong regional structure, Föreningsbanken, and one was an insurance company with links to the national white collar workers' union, SPP. Finally, the entrepreneurs kept their slice of the total number of shares.

\section{References}

Ansoff, I., \& E. McDonnell (1990) Implanting Strategic Management. London: Prentice-Hall.

Aslama, M., H. Hellman. T. Sauri (2004) Digitalizing Diversity: Public Service Strategies and Television Program Supply in Finland in 2002, The International Journal on Media Management, volume 6, No $3 \& 4,2004$.

Bagdikian, B.H. (2004) The New Media Monopoly. Boston: Beacon Press.

Blondel, J. (1987) Political Leadership. Beverly Hills: Sage

Brunsson, N. (1989) The Organization of Hypocrisy. New York: John Wiley.

Croteau, D. \& W. Hoynes (2001) The Business of Media. Corporate Media and the Public Interest. London: Pine Forge Press.

Chaadha, K. \& A. Kavoori (2005) 'Globalization and National Media Systems: Mapping Interactions in Policies, Markets and Formats', in Curran J. \& M. Gurevitch (2005) Mass Media and Society, $4^{\text {th }}$ edition. Oxford: Hodder Arnold.

Curran, J. (2005) 'Mediations of Democracy', in Curran J. \& M. Gurevitch (2005) Mass Media and Society, $4^{\text {th }}$ edition. Oxford: Hodder Arnold.

Curran J. \& M. Gurevitch (2005) Mass Media and Society, $4^{\text {th }}$ edition. Oxford: Hodder Arnold.

Doyle, G. (2002) Media Ownership. London: Sage.

Ewertsson, L (2001) The Triumph of Technology Over Politics? Reconstructing Television Systems: The Example of Sweden. Linköping: Linköping University.

Ewertsson, L., \& L. Hultcrantz (2004) Informationssamhällets institutioner: Att forma ramarna för affärsverkesamhet och konkurrens inom elektronisk kommunikation. [The institutions of the information society: forming the limits of business and competition in electronic communication] Stockholm: SNS Förlag.

Holmkvist, L. (2005) Grattis Björn [Congratulations, Björn] Resumé, January 27, 2005.

Hutchison, D. (1999) Media Policy. An Introduction. Oxford: Blackwell.

Karlsson, A. (1990) Om strategi och legitimitet - en studie av legitimitetsproblematiken i förbindelse med strategisk förändring. [On strategy and legitimacy - a study on the legitimacy problem in connection with strategic change] Lund: Lund University.

Lund, Anker Brink (2005) 'Institutionel konkurrenceevne på mediemarkedet' [Institutional competitiveness in the media market] Nordicom Information, no 4, 2005.

March, J.G., and J.P.Olsen (1989) Discovering Institutions. The Organization of Politics. N.Y.: The Free Press,

McQuail, D. (1992) Media Performance. Mass Communication and the Public Interest. London: Sage.

Melesko, S. (2005) Huvudlös värdering, [Senseless pricing] Pressens Tidning nr 1/2005

Napoli, P. (1997) A Principal-Agent Approach to the Study of Media Organizations: Toward a Theory of the Media Firm, Political Communication, 14: 207-219

Napoli, P. (2001/2003) Foundations of Communications Policy-Principles and Process in the Regulations of Electronic Media. Cresskill NJ: Hampton Press.

Selznick, P. (1957) Leadership in Administration. New York: Harper \& Row.

Siune, K. (1998) Changing Media and Changing Society, in McQuail, D. \& K. Siune (eds) Media Policy. Convergence, Concentration \& Commerce. London: Sage

Siune, K. \& O. Hulten (1998) Does Public Broadcasting Have a Future?, in McQuail, D. \& K. Siune (eds) Media Policy. Convergence, Concentration \& Commerce. London: Sage

Strøm,K. \& L. Svaasand (eds.) Challenges to Political Parties, Ann Arbor: University of Michigan Press.

Stuhlfaut, M.W. (2005) Economic Concentration in Agricultural Magazine Publishing: 1993-2002, Journal of Media Economics, 18(1): 21-33.

Sundin, S. (2002) Konsolidering och expansion 1930-1954 [Consolidation and expansion 1930-1954] Stockholm: Albert Bonniers förlag.

Syvertsen, T. (1997) Den store TV-krigen. Norsk allmennfjernsyn 1988-96. [The great media war. Norwegian public service TV 1988-1996] Bergen: Fagbokforlaget. 
Tjernström, S. (1998) Balance between Rights and Obligations of Public and Private Television - the Case of Sweden, commissioned by the Competition Directorate of the European Commission.

Tjernström, S. (1999) En svårstyrd skuta. Företagsledning i det svenska public service-företaget. Försvaret av sårbara värden i radio och tv. [The Public Service Skipper] Stockholm: Etermedierna i Sverige.

Van Cuilenberg, J \& D. McQuail (2003) Media Policy Paradigm Shift. Towards a New Communications Policy Paradigm, European Journal of Communication, Vol 18 (2): 181-207.

Whittington, R. (1993) What is Strategy - And does it Matter? London: Thomson.

Østbye, H. (1997) Media in Politics: Channels, Arenas, Actors, Themes, ch 10 in Strøm, K \& L: Svaasand (eds.): Challenges to Political Parties. Ann Arbor: University of Michigan Press.

\section{Sources}

Affärsvärlden

http://affarsvarlden.se/article.jsp?article=13767, published 040403, 16.48

http://affarsvarlden.se/article.jsp?article=82656, published 040915, 09.40

http://affarsvarlden.se/article.jsp? article=84394, published 041005, 22.00

http://affarsvarlden.se/article.jsp? article $=88212$, published 041110, 10.40

http://affarsvarlden.se/article.jsp?article $=91115$, published $041214,14.13$

http://affarsvarlden.se/article.jsp?article=91806, published 041222, 10.45

http://affarsvarlden.se/article.jsp?article=91909, published 041223, 09.01

http://affarsvarlden.se/article.jsp?article=19552, published 041223, 09.01

http://affarsvarlden.se/article.jsp?article $=92154$, published $041229,08.55$

http://affarsvarlden.se/article.jsp?article=92302, published 050103, 08.51

http://affarsvarlden.se/article.jsp?article $=92515$, published 050107, 08.03

http://affarsvarlden.se/article.jsp?article=92536, published 050107, 09.58

http://affarsvarlden.se/article.jsp?article=92584, published 050110, 07.05

http://affarsvarlden.se/article.jsp?article $=92789$, published $050111,14.42$

http://affarsvarlden.se/article.jsp?article=93695, published $050124,08.09$

http://affarsvarlden.se/article.jsp?article=94616, published 050201, 22.00

http://affarsvarlden.se/article.jsp?article=19228, published 050210, 08.44

http://affarsvarlden.se/article.jsp?article=19142, published 050213, 09.01

\section{Financial Times}

FT, November 1, 1991

FT, November 8, 1991

FT, March 4, 1994

FT, October 22, 1997

FT, December 24, 2004

FT, January 4, 2005

FT, January 10, 2005

FT, January 25, 2005

Dagens Nyheter
DN 031003
DN 041214
DN 041216
DN 041217
DN 041221
DN 041222
DN 041223
DN 041228
DN 050210
DN050221

Dagens Nyheter

DN 041214

DN 041216

DN 041217

DN 04122

DN 041223

DN 041228

DN050221

\author{
Svenska Dagbladet \\ SvD 040920 \\ SvD 041223 \\ SvD 041228 \\ SvD 050108 \\ SvD 050110 \\ SvD 050111 \\ SvD 050113 \\ SvD 050114 \\ SvD 050126 \\ SvD 050131 \\ SvD 050207 \\ SvD 050210 \\ SvD 050211 \\ SvD 050212
}

SUNE TJERNSTRÖM, Econ.D., Assistant Professor, Department of Communication and

Design, Kalmar University, sune.tjernstrom@hik.se 